\title{
Family presence during cardiopulmonary resuscitation and invasive procedures in children
}

\author{
Presença da família durante reanimação cardiopulmonar e procedimentos invasivos em crianças \\ Presencia de la familia durante reanimación cardiopulmonar y procedimientos invasivos en niños
}

Cristiana Araújo G. Ferreira¹, Flávia Simphronio Balbino², Maria Magda F. G. Balieiro², Myriam Aparecida Mandetta²

\section{ABSTRACT}

Objective: To identify literature evidences related to actions to promote family's presence during cardiopulmonary resuscitation and invasive procedures in children hospitalized in pediatric and neonatal critical care units.

Data sources: Integrative literature review in PubMed, SciELO and Lilacs databases, from 2002 to 2012, with the following inclusion criteria: research article in Medicine, or Nursing, published in Portuguese, English or Spanish, using the keywords "family", "invasive procedures", "cardiopulmonary resuscitation", "health staff", and "Pediatrics". Articles that did not refer to the presence of the family in cardiopulmonary resuscitation and invasive procedures were excluded. Therefore, 15 articles were analyzed.

Data synthesis: Most articles were published in the United States (80\%), in Medicine and Nursing (46\%), and were surveys (72\%) with healthcare team members (67\%) as participants. From the critical analysis, four themes related to the actions to promote family's presence in invasive procedures and cardiopulmonary resuscitation were obtained: a) to develop a sensitizing program for healthcare team; b) to educate the healthcare team to include the family in these circumstances; c) to develop a written institutional policy; d) to ensure the attendance of family's needs.

Conclusions: Researches on these issues must be encouraged in order to help healthcare team to modify their prac- tice, implementing the principles of the Patient and Family Centered Care model, especially during critical episodes.

Key-words: family; patient care team; cardiopulmonary resuscitation; pediatrics.

\section{RESUMO}

Objetivo: Identificar evidências da literatura sobre as ações promotoras da presença da família durante a reanimação cardiopulmonar e os procedimentos invasivos em crianças internadas em unidades de cuidados críticos pediátricos e neonatais.

Fontes de dados: Revisão integrativa da literatura nas bases de dados PubMed, Lilacs e SciELO, de 2002 a 2012, com os seguintes critérios de inclusão: artigo de pesquisa nas áreas de Medicina e de Enfermagem, publicado em língua portuguesa, inglesa ou espanhola e com as palavras-chave "família”, "procedimentos invasivos”, "reanimação cardiopulmonar", "equipe de saúde” e "pediatria”. Excluíram-se os artigos que não se referiam à presença da família durante os procedimentos invasivos e a reanimação cardiopulmonar, totalizando uma amostra de 15 artigos analisados.

Síntese dos dados: A maioria dos artigos foi publicada nos Estados Unidos (80\%), nas áreas de Medicina e de Enfermagem (46\%), sendo do tipo survey (72\%), com membros da equipe de saúde $(67 \%)$ como participantes.
Instituição: Escola Paulista de Enfermagem da Universidade Federal de São Paulo (Unifesp), São Paulo, SP, Brasil

'Escola Paulista de Enfermagem da Unifesp; Unidade Neonatal do Hospital São Paulo, São Paulo, SP, Brasil

Departamento de Enfermagem Pediátrica da Escola Paulista de Enfermagem da Unifesp, São Paulo, SP, Brasil
Endereço para correspondência:

Cristiana Araújo G. Ferreira

Rua Itapiru, 224 - Saúde

CEP 04143-010 - São Paulo/SP

E-mail: crisneonato@hotmail.com

Conflito de interesse: nada a declarar

Recebido em: 11/4/2013

Aprovado em: 27/6/2013 
A partir da análise crítica, obtiveram-se quatro temas representativos das ações para promover a presença da família nos procedimentos invasivos e na reanimação cardiopulmonar: a) elaborar um programa de sensibilização da equipe; b) capacitar a equipe para incluir a família nessas circunstâncias; c) elaborar uma política institucional declarada; d) atender às necessidades da família.

Conclusões: Deve-se incentivar as pesquisas sobre o tema, a fim de fornecer subsídios aos profissionais da área da saúde para modificarem sua prática, implementando os princípios do modelo do Cuidado Centrado no Paciente e Família, especialmente em situações de crise.

Palavras-chave: família; equipe de assistência ao paciente; ressuscitação cardiopulmonar; pediatria.

\section{ABSTRACT}

Objective: To identify literature evidence related to the actions to promote the presence of family members during Cardiopulmonary Resuscitation and Invasive Procedures in children hospitalized in pediatric and neonatal critical care units.

Data sources: Integrative literature review in PubMed, SciELO, and Lilacs databases, from 2002 to 2012, with the following inclusion criteria: research article in Medicine and Nursing, published in Portuguese, English, or Spanish, and using the keywords "family", "invasive procedures", "cardiopulmonary resuscitation", "health staff", and "pediatrics". Articles that did not refer to the presence of family members in cardiopulmonary resuscitation and in invasive procedures were excluded. A sample of 15 articles was analyzed.

Data synthesis: Most articles were published in the United States (80\%), in the areas of Medicine and Nursing (46\%), and were surveys $(73.2 \%)$, with healthcare team members $(67 \%)$ as participants. From the critical analysis, four themes related to the actions to promote family's presence in invasive procedures and cardiopulmonary resuscitation were obtained: a) to develop a sensitization program for the healthcare team; b) to train the healthcare team to include the family in these circumstances; c) to develop a written institutional policy; d) to meet the family's needs.

Conclusions: Researches on these issues must be encouraged in order to assist healthcare professionals to modify their practice, implementing the principles of the Patient and Family-Centered Care model, especially in critical episodes.

Key-words: family; patient care team; cardiopulmonary resuscitation; pediatrics.

\section{RESUMEN}

Objetivo: Identificar evidencias de la literatura sobre las acciones promotoras de la presencia de la familia durante la reanimación cardiopulmonar y los procedimientos invasivos en niños internados en unidades de cuidados críticos pediátricos y neonatales.

Fuentes de datos: Revisión integrativa de la literatura en las bases de datos PubMed, Lilacs y SciELO, de 2002 a 2012, con los siguientes criterios de inclusión: artículo de investigación en las áreas de Medicina y de Enfermería, publicado en lengua portuguesa, inglesa o española, y con las palabras clave «familia», "procedimientos invasivos», «reanimación cardiopulmonar», «equipo de salud»y «pediatría». Se excluyeron los artículos que no se referían a la presencia de la familia durante los procedimientos invasivos y la reanimación cardiopulmonar, totalizando una muestra de 15 artículos analizados.

Síntesis de los datos: La mayoría de los artículos fue publicada en Estados Unidos (80\%), en las áreas de Medicina y Enfermería (46\%), y era estudio de tipo survey $(73,2 \%)$, con miembros del equipo de salud (67\%) como participantes. A partir del análisis crítico, se obtuvieron cuatro temas representativos de las acciones para promover la presencia de la familia en los procedimientos invasivos y en la reanimación cardiopulmonar: a) elaborar un programa de sensibilización del equipo; b) capacitar al equipo para incluir a la familia en esas circunstancias; c) elaborar una política institucional declarada; d) atender a las necesidades de la familia.

Conclusiones: Se debe incentivar las investigaciones sobre el tema, a fin de suministrar subsidios a los profesionales del área de salud para que modifiquen su práctica, implementando los principios del modelo del Cuidado Centrado en el Paciente y en la Familia, especialmente en situaciones de crisis.

Palabras clave: familia; equipo de asistencia al paciente; resucitación cardiopulmonar; pediatría.

\section{Introduction}

In recent years, the Patient and Family-Centered Care (PFCC) model has been advocated as ideal by researchers around the world, being applied by health care professionals in the assistance of patients and their families in various health care institutions.

In this approach, the newborn (NB), the child, the adolescent, the adult, and the elderly come to be understood 
as members of a family and also as the focus of care by the health care team. In this scenario, the family is recognized as a customer in need of support, while it is encouraged to take care of its members, besides being an element of collaboration to an assistance planned jointly ${ }^{(1-7)}$.

This philosophy of care promotes family participation and recognizes it as a partner in the care, fostering its affective relationship with the $\mathrm{NB}$, a necessary aspect to promote their physical and emotional development ${ }^{(8,9)}$. On the national scene, particularly in the neonatal area, its applicability is not yet translated into nursing practice.

In the unit where assistance and education activities are performed, there is a strong concern to accompany the family members during the visit, to help them to learn and interact with the NB in this highly technological environment. However, the focus of care is still the NB alone, being the family the context of his care. Thus, the actions aim at meeting the biopsychic-affective needs of the NB and the team decides when and how the family should participate, restricting the room for choices. This approach differs from what has been recommended by the PFCC. An example is the permanence of family during cardiopulmonary resuscitation (CPR) and invasive procedures (IP). As there is no discussion or a written protocol on the topic, the participation of the family members depends on the health team, who allows or not their permanence during the performance of IPs and excludes them from CPR.

Despite the constant manifestations of discontentment, families undergo what is imposed to them, intensifying the feeling of vulnerability ${ }^{(10)}$. In order to change this reality and to make families feel cared for when going through this experience, one should question what actions promote the presence of the family during the CPR and IPS in pediatric and neonatal intensive care units. Grounded on this knowledge, the construction of guides and protocols can be proposed to guide the practice of health care professionals, including the family as an active participant in this process.

\section{Objective}

This study identified evidence from the literature on actions promoting the presence of family members during CPR and IPs in children hospitalized at pediatric and neonatal intensive care units.

\section{Method}

Descriptive research, which developed an integrative review of the literature on the presence of family members during CPR and IPs.

The integrative review is a method that seeks a complete review of studies on the subject investigated, to obtain a deep understanding of a particular phenomenon, based on previous studies. This allows the incorporation of evidence into practice, in order to gather and synthesize the results of studies on a delimited matter, in a systematic and orderly manner, besides deepening knowledge on the subject investigated. A review provides support for decision-making and the improvement of practice, providing a synthesis of the state of the knowledge about a specific topic, and a comprehensive analysis of the literature, contributing to discussions on methods and research results, besides identifying gaps in knowledge that need to be filled with new studies ${ }^{(11)}$.

In the present research, the following inclusion criteria were used: research article published in national and international journals, in Portuguese, English or Spanish, and indexed in the databases of the International Literature on Health Sciences (PubMed), the Scientific Electronic Library Online (SciELO) and the Latin American and Caribbean Health Sciences (Lilacs), in the period from 2002 to 2012. To do so, the following keywords were employed: "family", "invasive procedures", "cardiopulmonary resuscitation", "health team" and "pediatrics". Articles that did not refer to the family's presence in cardiopulmonary resuscitation and in invasive procedures were excluded.

In this literature search, 27 scientific articles were found. After reading the abstracts, 12 articles were excluded, because they did not meet the inclusion criteria and were not relevant to the study's question. Therefore, 15 scientific articles composed the sample.

Data were analyzed by reading each article and book report in full, using the instrument adapted from Ursi ${ }^{(12)}$.

The Qualitative Content Analysis, according to Morse and Field ${ }^{(13)}$, guided the analytical process to identify actions that promote the presence of the family in CPR and IPs in children hospitalized in pediatric and neonatal intensive care units. Based on the results of each study, initial codes were identified, grouped by similarities and differences in analytical categories, and the analysis of primary data patterns allowed the formation of thematic categories. 
Chart 1 - Summary of studies analyzed on the presence of the family in invasive procedures and pediatric cardiopulmonary resuscitation

\begin{tabular}{|c|c|c|c|c|c|c|}
\hline Authors & $\begin{array}{l}\text { Countryl } \\
\text { year }\end{array}$ & Area & Method & Subjects & Site of Collection & $\begin{array}{l}\text { Thematic categories of actions } \\
\text { promoting the presence of the } \\
\text { family during the CPR and IPs }\end{array}$ \\
\hline $\begin{array}{l}\text { Tinsley } \\
\text { et a/ }{ }^{14}\end{array}$ & $\begin{array}{l}\text { United States } \\
2008\end{array}$ & Medicine & $\begin{array}{l}\text { Descriptive } \\
\text { Survey }\end{array}$ & Family & Pediatric ICU & $\begin{array}{l}\text { - To develop a staff sensitization } \\
\text { program. } \\
\text { - To attend family's needs. }\end{array}$ \\
\hline $\begin{array}{l}\text { Sacchetti } \\
\text { et } a /^{15}\end{array}$ & $\begin{array}{l}\text { United States } \\
2005\end{array}$ & Medicine & $\begin{array}{l}\text { Prospective } \\
\text { observational } \\
\text { study }\end{array}$ & Family & $\begin{array}{l}\text { Department } \\
\text { of Pediatric } \\
\text { Emergency }\end{array}$ & $\begin{array}{l}\text { - To develop a staff sensitization } \\
\text { program. } \\
\text { - To attend family's needs. }\end{array}$ \\
\hline $\begin{array}{l}\text { Kuzin } \\
\text { et } a /^{16}\end{array}$ & $\begin{array}{l}\text { United States } \\
2007\end{array}$ & Medicine & $\begin{array}{l}\text { Descriptive } \\
\text { Survey }\end{array}$ & $\begin{array}{l}\text { Health Care } \\
\text { Professionals }\end{array}$ & $\begin{array}{l}\text { Symposium on } \\
\text { Pediatric Intensive } \\
\text { Care - } 2004\end{array}$ & $\begin{array}{l}\text { - To develop a staff sensitization } \\
\text { program. } \\
\text { - To develop a declared } \\
\text { institutional policy. } \\
\text { - To attend family's needs. }\end{array}$ \\
\hline $\begin{array}{l}\text { Fein } \\
\text { et } a /^{17}\end{array}$ & $\begin{array}{l}\text { United States } \\
2004\end{array}$ & $\begin{array}{l}\text { Medicine/ } \\
\text { Nursing }\end{array}$ & $\begin{array}{l}\text { Descriptive } \\
\text { Survey }\end{array}$ & $\begin{array}{l}\text { Physicians/ } \\
\text { nurses/resident } \\
\text { physicians }\end{array}$ & $\begin{array}{l}\text { Department } \\
\text { of Pediatric } \\
\text { Emergency }\end{array}$ & $\begin{array}{l}\text { - To develop a staff sensitization } \\
\text { program. } \\
\text { - Train staff to include the family in } \\
\text { these circumstances. }\end{array}$ \\
\hline $\begin{array}{l}\text { Gold } \\
\text { et } a /^{18}\end{array}$ & $\begin{array}{l}\text { United States } \\
2006\end{array}$ & Medicine & $\begin{array}{l}\text { Descriptive } \\
\text { Survey }\end{array}$ & Physicians & $\begin{array}{l}\text { Department } \\
\text { of Pediatric } \\
\text { Emergency }\end{array}$ & $\begin{array}{l}\text { - To develop a staff sensitization } \\
\text { program. } \\
\text { - To develop a declared } \\
\text { institutional policy. }\end{array}$ \\
\hline Maxton $^{19}$ & $\begin{array}{l}\text { Australia } \\
2008\end{array}$ & $\begin{array}{l}\text { Medicine/ } \\
\text { Nursing }\end{array}$ & $\begin{array}{l}\text { Descriptive } \\
\text { of qualitative } \\
\text { approach/ } \\
\text { phenomenology }\end{array}$ & Family & Pediatric ICU & $\begin{array}{l}\text { - To develop a staff sensitization } \\
\text { program. } \\
\text { - To develop a declared } \\
\text { institutional policy. }\end{array}$ \\
\hline $\begin{array}{l}\text { Fulbrook } \\
\text { et } a^{20}\end{array}$ & $\begin{array}{l}\text { United } \\
\text { Kingdom } \\
2007\end{array}$ & Nursing & $\begin{array}{l}\text { Descriptive } \\
\text { Survey }\end{array}$ & Nurses & $\begin{array}{l}\text { 8th Symposium } \\
\text { on Pediatric } \\
\text { Intensive Care - } \\
2002 .\end{array}$ & $\begin{array}{l}\text { - Train staff to include the family in } \\
\text { these circumstances. } \\
\text { - To develop a declared } \\
\text { institutional policy. } \\
\text { - To attend family's needs. }\end{array}$ \\
\hline $\begin{array}{l}\text { O'Brien } \\
\text { et } a^{21}\end{array}$ & $\begin{array}{l}\text { United States } \\
2002\end{array}$ & $\begin{array}{l}\text { Medicine/ } \\
\text { Nursing }\end{array}$ & $\begin{array}{l}\text { Descriptive } \\
\text { Survey }\end{array}$ & $\begin{array}{l}\text { Physicians/ } \\
\text { resident } \\
\text { physicians }\end{array}$ & $\begin{array}{l}\text { Annual Meeting } \\
\text { of the American } \\
\text { Academy of } \\
\text { Pediatrics }\end{array}$ & $\begin{array}{l}\text { - Train staff to include the family in } \\
\text { these circumstances. } \\
\text { - To develop a declared } \\
\text { institutional policy. }\end{array}$ \\
\hline $\begin{array}{l}\text { Bradford } \\
\text { et al2 }\end{array}$ & $\begin{array}{l}\text { United States } \\
2005\end{array}$ & Medicine & $\begin{array}{l}\text { Descriptive } \\
\text { Survey }\end{array}$ & $\begin{array}{l}\text { Resident } \\
\text { physicians }\end{array}$ & $\begin{array}{l}\text { Department of } \\
\text { Pediatrics }\end{array}$ & $\begin{array}{l}\text { Train staff to include the family in } \\
\text { these circumstances. }\end{array}$ \\
\hline $\begin{array}{l}\text { Waseem e } \\
\text { Ryan }^{23}\end{array}$ & $\begin{array}{l}\text { United States } \\
2003\end{array}$ & Medicine & $\begin{array}{l}\text { Descriptive } \\
\text { Survey }\end{array}$ & $\begin{array}{l}\text { Physicians/ } \\
\text { resident } \\
\text { physicians }\end{array}$ & $\begin{array}{l}\text { Department } \\
\text { of Pediatric } \\
\text { Emergency }\end{array}$ & $\begin{array}{l}\text { Train staff to include the family in } \\
\text { these circumstances. }\end{array}$ \\
\hline $\begin{array}{l}\text { Mangurten } \\
\text { et } a{ }^{24}\end{array}$ & $\begin{array}{l}\text { United States } \\
2006\end{array}$ & $\begin{array}{l}\text { Medicine } \\
\text { /Nursing }\end{array}$ & $\begin{array}{l}\text { Descriptive } \\
\text { Survey }\end{array}$ & $\begin{array}{l}\text { Family/nurses/ } \\
\text { physicians/ } \\
\text { resident } \\
\text { physicians }\end{array}$ & $\begin{array}{l}\text { Department } \\
\text { of Pediatric } \\
\text { Emergency }\end{array}$ & $\begin{array}{l}\text { - Train staff to include the family in } \\
\text { these circumstances. } \\
\text { - To develop a declared } \\
\text { institutional policy. } \\
\text { - To attend family's needs. }\end{array}$ \\
\hline
\end{tabular}


Chart 1 - Continuation

\begin{tabular}{|c|c|c|c|c|c|c|}
\hline Authors & $\begin{array}{l}\text { Countryl } \\
\text { year }\end{array}$ & Area & Method & Subjects & Site of Collection & $\begin{array}{l}\text { Thematic categories of actions } \\
\text { promoting the presence of the } \\
\text { family during the CPR and IPs }\end{array}$ \\
\hline $\begin{array}{l}\text { Henderson } \\
\text { et } a^{27}\end{array}$ & $\begin{array}{l}\text { United } \\
\text { States/2006 }\end{array}$ & $\begin{array}{l}\text { Medicine } \\
\text { /Nursing }\end{array}$ & $\begin{array}{l}\text { Methodological } \\
\text { research } \\
\text {-RAND/UCLA } \\
\text { Appropriateness } \\
\text { Method }\end{array}$ & $\begin{array}{l}20 \\
\text { representatives } \\
\text { of } 18 \text { national } \\
\text { organizations } \\
\text { with an interest } \\
\text { in pediatric } \\
\text { emergency }\end{array}$ & $\begin{array}{l}\text { National } \\
\text { Consensus } \\
\text { Conference. } \\
\text { Washington DC, } \\
2003 \text {. }\end{array}$ & $\begin{array}{l}\text { - To develop a declared } \\
\text { institutional policy. } \\
\text { - To attend family's needs. }\end{array}$ \\
\hline $\begin{array}{l}\text { Beckman } \\
\text { et } a^{28}\end{array}$ & $\begin{array}{l}\text { United } \\
\text { States/2002 }\end{array}$ & $\begin{array}{l}\text { Medicine } \\
\text { /Nursing }\end{array}$ & $\begin{array}{l}\text { Descriptive } \\
\text { Survey }\end{array}$ & $\begin{array}{l}\text { Physicians/ } \\
\text { nurses/resident } \\
\text { physician }\end{array}$ & $\begin{array}{l}\text { Department } \\
\text { of Pediatric } \\
\text { Emergency }\end{array}$ & To attend family's needs. \\
\hline
\end{tabular}

CPR: cardiopulmonary resuscitation; IP: invasive procedures; RAND: research and development; UCLA: University of California, Los Angeles.

\section{Data synthesis}

Among the 15 items that composed the study sample (Chart 1), most of them $(12 ; 80 \%)$ was performed in the United States; two (13\%) were developed in Europe, and one (7\%), in Australia, all in English. In Brazil, in the databases searched, no publication was located on the subject during the study period.

As for the area of knowledge, seven (46\%) were conducted in partnership between the areas of Medicine and Nursing; seven (46\%) were developed in the field of Medicine and one $(8 \%)$, in Nursing.

In 11 articles (73.2\%), the descriptive survey method was adopted; in one $(6.7 \%)$, phenomenological qualitative research; in one $(6.7 \%)$, prospective trial; in one $(6.7 \%)$, prospective observational study; and in one (6.7\%), methodological research. Participants were mostly members of the healthcare team (67\%) and family (33\%).

As for actions promoting family presence during CPR and IPs, four thematic categories emerged: a) to develop a staff sensitization program; b) to train the team to include the family in these circumstances; c) to developed a declared institutional policy; d) to meet the family's needs.

In this article, each category is presented with the related publications.

\section{To develop a staff sensitization program}

This action promotes the inclusion of the family and restores its competences, making it essential to promote the modification of professionals' restrictive beliefs about family presence in CPR and in IPs.

One strategy is to discuss with professionals about the experience of families who witnessed these circumstances. Authors of studies that heard the family members realized that those who could witness the CPR or some IP would like to participate again, considering it was important because they felt less anxious when witnessing.

Authors emphasize that the condition of not being able to be next to the child contributes to the emotional trauma of parents ${ }^{(14,15)}$. Professionals need to be aware that the families who attended a successful CPR of the child argue that it was difficult to be present, but it would be worse if they were not. Parents considered it important to see with their own eyes what was going on with their child ${ }^{(14,15)}$.

Another important element to sensitize professionals is to recognize the advantages that family presence promotes, such as strengthening the bond between the family and the healthcare team; maintenance of information to the family about the clinical condition of the child; aid in the grieving process if the child does not survive; reassurance of the child 
during the procedure; emotional security of the child to endure fear; and guarantee to the family of witnessing the last moments of life of the child ${ }^{(14-19)}$.

\section{To train the health staff to include the family}

This is a necessary action, identified by health professionals in their daily lives. In the articles, the authors show that professionals with longer careers and experience in the management of CPR in children feel more comfortable with the presence of family in the events, unlike doctors with less training time, such as residents. Thus, the results point to the need for training staff in institutions and the inclusion of the theme in undergraduate and graduate programs in order to encourage a better contemplated practice in the future ${ }^{(17,20-25)}$.

\section{To develop a declared institutional policy}

This strategy aims to promote the family presence during CPR and IPs. In some articles ${ }^{(16,18,20,21,26)}$, the authors identified that this action is essential to ensure access to the family, outlining the conditions and defining the responsibilities of each team member regarding the care and supervision of the family in that difficult occasion.

In these studies, physicians and nurses considered that, in the area of Pediatrics, the presence of the family in these circumstances has been more accepted because there is a closer relationship between professionals and family members, considering that these are the main responsible for the child's health care ${ }^{(16,18,20,21,26)}$.

Institutions with declared policy on the presence of family members prove, through research, that this practice does not interfere in the care provided to the child, does not extend the time spent, and does not affect the efficiency of the team during the $\mathrm{CPR}^{(19,24)}$.

Representatives of 18 organizations have developed recommendations on the practice of family presence during CPR and IPs, which were approved by the American Academy of Pediatrics, being:

- considering the presence of the family members as an option to them;

- assessing in advance the conditions of the family, in search for factors that may affect their participation, such as the psychological state;

- predefining a member of the family to witness the procedure;

- evaluating the ability of the health care professional in case of tragic experiences;
- training healthcare professionals to elect a team member to supports the family during procedures;

- considering the safety of health professionals;

- documenting the reasons, in case the option of family presence is not offered;

- implementing the policy of presence of the family in the institution;

- reviewing the protocols continuously;

- promoting research about the practice according to the perception of family, the patient, and the health professionals ${ }^{(27)}$.

\section{To meet the family's needs}

In pediatric and neonatal intensive care units in the U.S., there is a growing acceptance by the healthcare teams regarding the presence of the family in the CPR an IPs, as they believe this practice brings benefits to the patient. However, they recommend that the family receives the option to remain or not with the child in those moments, after evaluating the condition of the unit, the health care professionals, and the family member ${ }^{(16,20,24,26-28)}$.

Studies show that the family needs to be informed and witness the situations to which their child is subjected during hospitalization. Therefore, it is essential the presence of a professional trained to support the family members in this context, welcoming them, comforting them, answering their questions, clarifying the procedures, and ensuring the safety of patients and professionals involved ${ }^{(14,15,27)}$.

\section{Conclusion}

In the literature, researchers seek theoretical and practical grounding for the presence of the family during the CPR and the IPs, in order to identify the best evidence for its implementation.

Most studies have been conducted in the United States, in the areas of Medicine and Nursing, through surveys, and the subjects are members of the healthcare team. In the national literature, there were no studies on this thematic that assessed the perspective of who cares and who is cared for.

From the qualitative analysis of the results of the studies analyzed, were obtained four thematic categories that represent the actions promoting the presence of the family members in CPR and IPs in units of pediatric and neonatal critical care.

Considering that these actions were identified based on data from studies conducted in different assistance cultures 
and contexts, it is necessary to investigate the perception of health professionals and families in our reality in order to understand the values, attitudes, and behaviors regarding the presence of family members in CPR and IPs. This provides data for the development of assistance protocols that address the families' needs, in order to change a practice that is still

\section{References}

1. Jolley J, Shields L. The evolution of family-centered care. J Pediatr Nurs 2009;24:164-70.

2. MacKean GL, Thurston WE, Scott CM. Bridging the divide between families and health professionals' perspectives on family-centered care. Health Expect 2005;8:74-85.

3. Mikkelsen G, Frederiksen K. Family-centred care of children in hospital - a concept analysis. J Adv Nurs 2011;67:1152-62.

4. Coyne I, Cowley S. Challenging the philosophy of partnership with parents: a grounded theory study. Int J Nurs Stud 2007;44:893-904.

5. Shields L, Pratt J, Hunter J. Family centred care: a review of qualitative studies. J Clin Nurs 2006;15:1317-23.

6. Shields L, Zhou H, Pratt J, Taylor M, Hunter J, Pascoe E. Family-centred care for hospitalised children aged 0-12 years. Cochrane Database Syst Rev [serial on the Internet]. 2012;10:CD004811 [cited 2012 May 10]. Available from: http:// www.ncbi.nlm.nih.gov/pubmed/23076908

7. Institute for Patient- and Family-Centered Care [homepage on the Internet]. Patient- and Family-Centered Care core concepts [cited 2012 Aug 20]. Available from: http://www.ipfcc.org/faq.html

8. Hughes M. Parents' and nurses' attitudes to family-centred care: an Irish perspective. J Clin Nurs 2007;16:2341-8.

9. Priddis L, Shields L. Interactions between parents and staff of hospitalised children. Paediatr Nurs 2011;23:14-20.

10. Leite El. Vulnerabilidade da família no contexto da Unidade de Terapia Intensiva Neonatal [tese de mestrado]. São Paulo (SP): Unifesp; 2011.

11. Sampieri RH, Collado CF, Lucio PB. Metodologia de pesquisa. $3^{\text {rd }}$ ed. São Paulo: McGraw-Hill; 2006.

12. Ursi ES, Gavão CM. Perioperative prevention of skin injury: an integrative literature review. Rev Latino-Am Enfermagem 2006;14:124-31.

13. Morse JM, Field PA. Nursing research: the application of qualitative approaches. $2^{\text {nd }}$ ed. United Kingdom: Nelson Thomes Ltda; 1996.

14. Tinsley C, Hill JB, Shah J, Zimmerman G, Wilson M, Freier K et al. Experience of families during cardiopulmonary resuscitation in a pediatric intensive care unit. Pediatrics 2008;122:799-804.

15. Sacchetti A, Paston C, Carraccio C. Family members do not disrupt care when present during invasive procedures. Acad Emerg Med 2005; 12:477-9. centered on the individual and move towards a direction that covers the core principles of the PFCC model.

It is also necessary to invest in the continuing education of professionals so as to strengthen approaches, behaviors, and values that promote the presence and partnership with the family in caring for the child.
16. Kuzin JK, Yborra JG, Taylor MD, Chang AC, Altman CA, Whitney GM et al. Familymember presence during interventions in the intensive care unit: perceptions of pediatric cardiac intensive care providers. Pediatrics 2007;120:895-901.

17. Fein JA, Ganesh J, Alpern ER. Medical staff attitudes toward family presence during pediatric procedures. Pediatr Emerg Care 2004;20:224-7.

18. Gold KJ, Gorenflo DW, Schwenk TL, Bratton SL. Physician experience with family presence during cardiopulmonary resuscitation in children. Pediatr Crit Care Med 2006;7:428-33.

19. Maxton FJ. Parental presence during resuscitation in the PCIU: the parents experience. Sharing and surviving the resuscitation: a phenomenological study. J Clin Nurs 2008;17:3168-76.

20. Fulbrook P, Latour JM, Albarran JW. Paediatric critical care nurses' attitudes and experiences of parental presence during cardiopulmonary resuscitation: a European survey. Int J Nurs Stud 2007;44:1238-49.

21. O'Brien MM, Creamer KM, Hill EE, Welham J. Tolerance of family presence during pediatric cardiopulmonary resuscitation: a snapshot of military and civilian pediatricians, nurses, and residents. Pediatr Emerg Care 2002;18: 409-13.

22. Bradford KK, Kost S, Selbst SM, RenwickAE, Pratt A. Family member presence for procedures: the resident's perspective. Ambul Pediatr 2005;5:294-7.

23. Waseem M, Ryan M. Parental presence during invasive procedures in children: what is the physician's perspective? South Med J 2003;96:884-7.

24. Mangurten J, Scott SH, Guzzetta CE, ClarkAP, Vinson L, Sperry J et al. Effects of family presence during resuscitation and invasive procedures in a pediatric emergency department. J Emerg Nurs 2006;32:225-33.

25. Dudley NC, Hansen KW, Furnival RA, Donaldson AE, Van Wagenen KL, Scaife ER. The effect of family presence on the efficiency of pediatric trauma resuscitations. Ann Emerg Med 2009;53:777-84.

26. Egemen A, Ikizoǧlu T, Karapnar B, Coşar H, Karapnar D. Parental presence during invasive procedures and resuscitation: attitudes of health care professionals in Turkey. Pediatr Emerg Care 2006;22:230-4.

27. Henderson DP, Knapp JF. Report of the National Consensus Conference on Family Presence During Pediatric Cardiopulmonary Resuscitation and Procedures. J Emerg Nurs 2006;32:23-9.

28. Beckman AW, Sloan BK, Moore GP, Cordell WH, Brizendine EJ, Boie ET et al. Should parents be present during emergency departament procedures on children, and who should make that decision? A survey of emergency physician and nurse attitudes. Acad Emerg Med 2002;9:154-8. 